\title{
ANALISIS STRATEGI PEMASARAN PRODUK PERUMAHAN MENGGUNAKAN FISHBONE
}

\author{
Moch. Shohib \\ Magister Teknik Industri, Fakultas Teknologi Industri Institut Teknologi Adhi Tama Surabaya \\ maddsho@gmail.com \\ Indung Sudarso \\ Magister Teknik Industri, Fakultas Teknologi Industri Institut Teknologi Adhi Tama Surabaya \\ indungsudarso27@gmail.com
}

\begin{abstract}
Networking and modulary sesion dengan kemajuan teknologi telah menghasilkan perubahan signifikan dalam cara pengelolahan sistem pemasaran dan administrasi dalam memberikan layanan mereka sehingga straregi pemasaran dengan memafaatkan media sosial dan situs web, meskipun adanya strategi online, direct selling atau pengelolahan ofline perusahaan dalam memberikan layanan marketing tidak dapat dihilangkan. Metode kualitatif digunakan dalam penelitian ini untuk mengetahui strategi marketing PT. X menganalisis penyebab turunnya pemasaran PT. X ditinjau menggunakan fishbone. Hasil analisis diagram fishbone menunjukan bahwa faktor man power kurangnya pelatihan karyawan, method tidak adanya SOP penjulan, kurangnya kreatifitas karyawan dalam penggunaan metode pemasaran, manchine kurangnya dukungan sarana pembuatan iklan pemasaran dan pengelolahan administrasi serta tidak adanya sistem pendukung administrasi yang menjadi penyebab permasalahan penurunan jumlah pemasaran dan pemasaran tidak terkontrol secara sistematis.
\end{abstract}

Keywords: Strategi Pemasaran, Fishbone.

\section{PENDAHULUAN}

Industrial di Amerika Serikat menggunakan strategi pemasaran melalui iklan ofline dan iklan spanduk seluler dalam memasarkan produk mereka dikarenakan banyaknya konsumen yang berjumlah hampir 200 juta atau sekitar $80 \%$ berasal dari pasar seluler (Osinga dan Zevenbergen, 2019). Indonesia juga menerapkan strategi marketing online dengan memanfaatkan media sosial facebook, instargram sebagai media pemasaran (Marchand dan Flemming, 2020; Mulyana dkk., 2020) bahkan situs web dan dan aplikasi android juga digunakan sebagai media pemasaran produk (Asmara, 2021; dan Fernando dkk, 2021).

Straregi pemasaran dengan memafaatkan media sosial dan situs web merupakan dampak dari perkembangan industri 4.0 yang mengarah pada networking and modulary sesion. Kemajuan teknologi telah menghasilkan perubahan signifikan dalam cara beberapa organisasi layanan memberikan layanan mereka. Secara khusus, layanan yang secara tradisional disampaikan melalui kontak 
pribadi antara karyawan organisasi dan pelanggannya sekarang dapat sering disampaikan secara online melalui media sosial dengan kontak langsung yang minimal antara kedua pihak untuk menghemat waktu pemasaran dan memudahkan para pelaku industri untuk mengelolah dan memasarkan produk yang mereka miliki pada konsumen (Chatzigeorgiou dan Christou, 2020).

Penggunaan strategi pemasaran wajib memenuhi ketentuan Undang-undang No. 7 Tahun 2014 pasal 65. Bahkan pada UU No. 72014 juga disebutkan bahwa perdagangan yang melalui sistem elektronik harus menyediakan data dan informasi secara benar. Data yang dimaksud berupa identitas dan legalitas pelaku usaha, detail barang yang dijual beserta harganya, prosedur transaksi barang. Perdagangan sistem elektronik wajib memenuhi ketentuan undang-undang penggunaan sistem transaksi elektronik perdagangan. Jika terjadi sengketa antara pihak penyedia barang dan konsumen bisa diselesaikan dengan jalur hukum dan berpotensi pencabutan izin pelaku usaha (Kemendag, 2014). Pada tahun 2019 pemerintah juga telah mengeluarkan Peraturan Pemerintah tentang Perdagangan Melalui Sistem Elektronik untuk merespon perkembangan strategi pemasaran yang menggunakan elektronik sebagai media pemasaran (Kemendag, 2019).

Strategi marketing konvensional yang menggunakan media cetak dinilai kurang efektif dalam desain strategi marketing industri, tak terkecuali pada desain strategi developer perumahan sehingga pemasaran juga dilakukan melalui sistem online seperti PT. San Esha Arthamas yang mulai menggunakan web dalam pemasaran perumahannya (Mincarti dan Mulyono, 2020). PT. Grand Zam-Zam Residence menggunakan media sosial seperti facabook, twitter, instagram, dll (Caturini dkk, 2020). Munculnya strategi marketing online bukan berarti menghilangkan strategi ofline. Strategi marketing ofline dengan nama lain direct selling atau metode penjualan langsung tidak dapat dihilangkan karena direct selling merupakan metode pemasaran langsung yang dilakukan oleh produsen dengan menawarkan contoh barang melalui media cetak seperti pamflet, brosur, banner ataupun iklan outdoor (Cahyono dkk, 2017).

PT. X merupakan perusahaan yang brgerak pada bidang developer perumahan yang berdiri mulai tahun 2006, awalnya PT. X berkecipung pada dunia dekorasi, namun terus mengembangkan usahanya menjadi developer perumahan, saat ini PT. X sudah menyelesaikan 15 proyek perumahan. PT. X berfokus membangun rumah layak huni di lokasi yang strategis dan bernilai investasi tinggi dengan jenis bangunan rumah bersubsidi dan komersil. Selain PT. X juga ada PT. ABC dan PT. XYZ yang termasuk developer perumahan besar di Lumajang. Tahun 2019 PT. X mampu menguasi pasar dengan hasil penjualan 113 unit Perumahan yang terjual, sedangkan PT.ABC unggul jumlah penjualan di tahun 2018 dengan jumlah 33 unit yang berhasil dijual. Ada 300 perumahan perumahan sudah dipasarkan oleh ketiga developer tersebut, namun setelah masuknya pandemi di 
Indonesia pada awal tahun 2020 membuat para peminat perumahan menurun drastis sehingga sangat berpengaruh pada pemasaran. Berikut grafik penjualan tiga perumahan di Lumajang dalam waktu empat tahun terakhir.

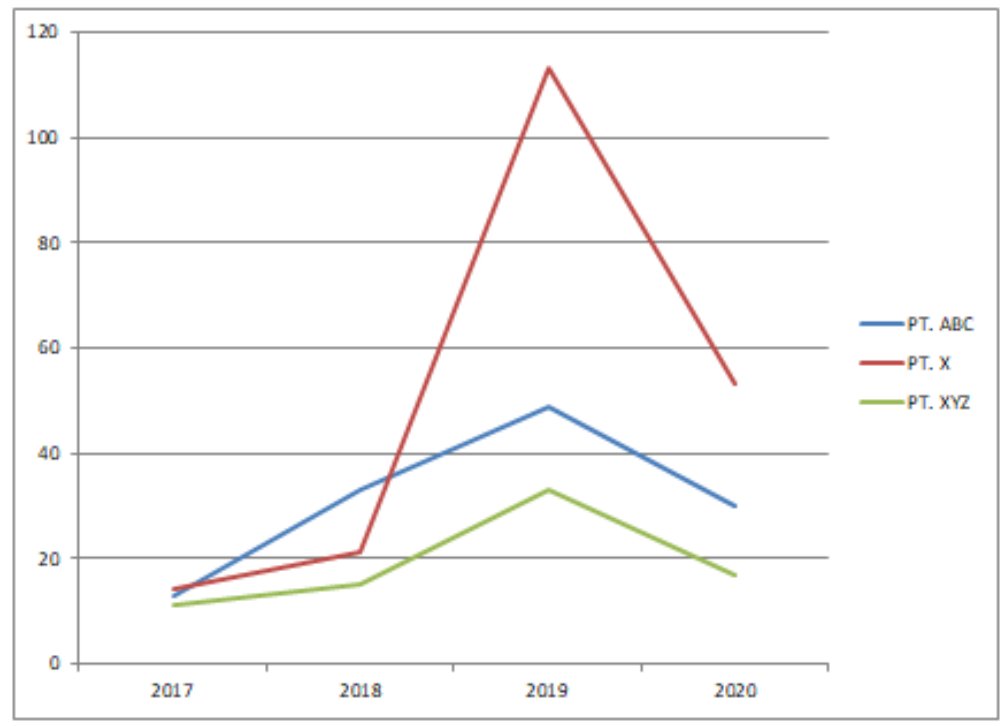

Gambar 1.1 Grafik presentase pemasaran

Tabel grafik pemasaran di atas menunjukan bahwa PT. X yang di tahun 2019 menguasai segmen pasar perumahan di Lumajang namun di tahun 2020 mengalami penurunan yang sangat dignifikan dibanding para pesaingnya sehingga PT. X mengalami penurunan omset yang juga cukup drastis di tahun 2020. Tahun 2021 pemasaran PT. X masih belum menunjukan kestabilan pejualan meskipun saat ini memiliki dua lokasi perumahan baru dan satu lokasi perluasan perumahan yang sudah habis terjual. Tiga lokasi tersebut memiliki kapasitas jumlah bangunan dengan beberapa tipe varian, terutama perumahan yang subsidi. Pandemi yang membuat sektor perbangkan menutup kran pendanaan KPR pada developer perumahan menjadi salah satu penyebab penurunan pemasaran, kendala lain yang sering terjadi proses pemasaran adanya data merah konsumen di BI cheking sehingga seringkali konsumen yang berminat membeli terkendala dan banyak yang mengurungkan niat pembeliannya. Dari beberapa permasalahan yang telah dibutuhkan strategi baru untuk memasarkan produk PT. X Lumajang. 


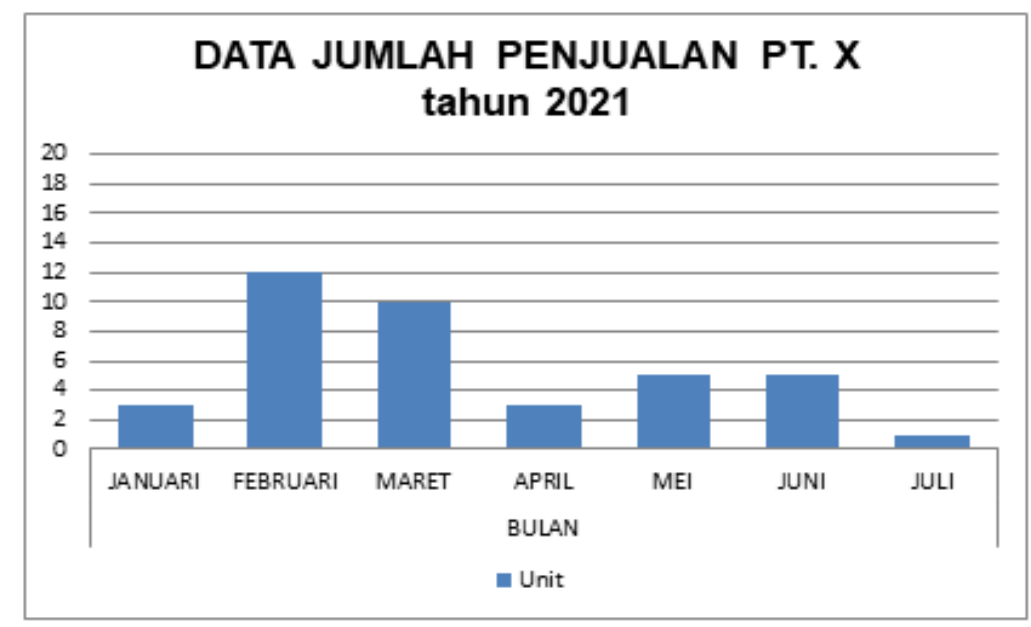

Gambar 1.2 Grafik presentase pemasaran

Penurunan pemasaran tidak hanya dialami oleh PT. X tapi semua perusahaan yang bergelut pada developer perumahan juga mengalami penurunan. Adanya penurunan pemasaran tersebut disebabkan adanya pandemi yang berdampak pada perekonomian. Strategi pemasaran yang dipakai PT. X sama seperti perusahaan yang bergerak pada sektor perumahan yang lainnya, yaitu dengan menerapkan sistem pemasaran melalui pemasaran ofline dan online. Strategi pemasaran ofline yang menggunakan media promosi banner yang ditaruh di lokasi perumahan PT. X dan di sebarkan di wilayah kabupaten Lumajang masih belum mampu meningkatkan pemasaran PT. X Lumajang di smester awal 2021, begitu juga strategi pemasaran online yang menggunakan website, media sosial facebook, Instagram dan Whatsapp juga tidak memberikan dampak peningkatan pemasaran PT. X mulai adanya pandemi sampai saat ini, padahal media pemasaran online dan ofline yang digunakan PT. X sebelumnya memberikan dampak pada penjualan perumahan PT. X.

Fishbone merupakan serangkaian metode analisis seven tools sebagaimana penelitian yang telah dilakuan Iriani et.all (2020) menggunakan diagram fishbone untuk mengetahui penyebab permasalahan yang terjadi pada produk stamping agar mendapatkan solusi dan meminimalisir cacat yang dapat terjadi di masa depan dan penelitian yang dilakukan oleh Khodijah (2015) menggunakan diagram fishbone untuk menganalisis faktor-faktor yang menjadi penyebab kerusakan produk pada proses cetak produk pada PT. Temprina Media Grafika Semarang. Berdasarkan beberapa penelitian di atas peneliti menggunakan diagram fishbone untuk mengetahui untuk mengetahui strategi marketing PT. X menganalisis penyebab turunnya pemasaran PT. X menggunakan fishbone. 


\section{KAJIAN PUSTAKA DAN PENGEMBANGAN HIPOTESIS}

\section{Strategi Pemasaran}

Diskursus bahasa strategi memiliki artian suatu diskursus ilmu yang memiliki corak seni dalam menggunakan sumber daya untuk mencapai suatu tujuan (KBBI). Pemasaran sendiri berarti sebuah cara atau tindakan dalam menjual suatu barang (KBBI). Strategi pemasaran merupakan sebuah serangkaian cara untuk mencapai suatu hal yang diinginkan oleh perusahaan dari waktu ke waktu sebagai benruk responsi perusahaan dalam menghadapi situasi dan kondisi yang secara waktu dapat berubah-ubah. Dalam perspektif lain, makna strategi pemasaran dapat diartikan sebagai suatu bentuk usaha yang dilakukan oleh pihak produsen da;am memberikan nilai lebih kepada konsumen sehingga konsumen dapat tertarik kepada sesuatu yang ditawarkan dan keuntungan tetap ada pada pihak produsen maupun konsumen (Hati, Srisusilawati, dan Wijaya 2020). Strategi pemasaran merupakan suatu rencana yang memiliki dasar atau patokan pada hasil riset pasar, penilaian akan produk, perencanaan pemasaran produk, promosi produk, terget penjualan dan penyaluran produk yang digunakan untuk mengembangkan pemasaran dalam kurun waktu yang singkat maupun kurun waktu yang lama (KBBI).

Philip Kotler (2009) mengartikan pemasaran dari dua sudut pandang. Pertama dari sudut menejerial, pemasran merupakan sebuah strategi spesifik untuk meraih pangsa pasar, ide konsep, harga, promosi, dan distribusi, yang diaplikasikan guna mengahsilkan peluang dan menciptakan kepuasan individu dan sesuai dengan tujuan perusahaan. Kedua dari masyarakat (socielaty), artinya pemasaran adalah proses dimana seorang konsumen dalam memenuhi kebutuhan dan keinginannya melalui penciptaan, penawaran, dan pertukaran atas barang dan jasa yang dibutuhkan. Sedangkan menurut Santoso dalam Khotijah menyatakan bahwa pemasaran merupakan serangkaian kegiatan bisnis mulai dari konsep produk, penentuan harga jual, promosi atau penawaran produk, pendistribusikan barang dan jasa untuk memberikan kepuasan dalam memenuhi kebutuhan dan keinginan konsumen (Khotijah, 2004). Dari pengertian tersebut dapat diambil kesimpulan bahwa pemasaran serangkaian perencanaan dan penjualan produk guna memberi kepuasan pelanggan dan mencapai target pangsa pasar perusahaan. Pemasaran merupakan suatu ujung tombak perusahaan, barometer atau standarisasi dari keberhasilan pemasaran adalam peraihan pangsa pasar. Keberlangsungan pemasaran madalah wujud bahwa perusahaan bisa mempertahankan hidup perusahaan, perkembang perusahaan (Kotler, 2009).

Assauri (2018) dalam bukunya menyebutkan bahwa srategi sebenarnya merupakan serangkaian upaya yang akan digunakan oleh perusahaan atau organisasi dalam menjalankan misi dan tujuan yang akan dijalankan perusahaan. Strategi bisa dijadikan tolak ukur sebuah perusahaan dalam melaksanakan perencanaan, strategi yang digunakan oleh perusahaan mengacu pada tujuan dan misi perusahaan dengan 
mempertimbangkan beberapa hal; faktor kekuatan kondisi internal usaha, kelemahan dalam internal yang dikenalnya, mampu membaca situasi dan kondisi dalam usaha sehingga tahu peluang dan kesempatan yang akan didapatkan dalam melakukan strategi pemasaran. Dengan demikian hal yang diinginkan dalam melakukan strategi pemasaran tercapai dengan baik (Misra Hartati, 2016). Berdasarkan pengertian di atas disimpulkan bahwa strategi pemasaran adalah rencana didukung dengan fakta-fakta yang ada melalui pertimbangan kondisi persaingan dan lingkungan yang selalu berubah agar mencapai tujuan yang diharapkan untuk memasarkan produk yang mereka miliki sesuai dengan tujuan perusahaan. Jadi dalam penetapan strategi pemasaran yang akan dijalankan perusahaan haruslah terlebih dahulu melihat situasi dan kondisi pasar serta menilai posisinya di pasar agar dapat menentukan kegiatan pemasaran yang harus dilaksanakan.

\section{Diagram Fishbone}

Diagram fishbone merupakan sebuah diagram yang memuat sebab akibat atau biasa disebut sebagai diagram Ishikawa atau diagram tulang ikan, dan cause and effect (Iriani et al, 2020). Fishbone merupakan bagian dari Seven tools yang merupakan beberapa alat bantu untuk pengolahan data dalam upaya pengendalian kualitas, peningkatan mutu produk atau perbaikan sistem kerja, yang mana seven tools juga disebut dengan metode perangkat yang digunakan untuk mengendalikan kualitas melalui analisis permasalahan produksi dalam perbaikan yang dikenalkan oleh Kaoru Ishikawa pada tahun 1968 (Iriani et al, 2020). Diagram fishbone yang merupakan alat analisis untuk mengidentifikasi atau menganalisis berbagai sebab yang memiliki potensi dari satu efek atau masalah, kemudian menganalisis masalah tersebut melalui tahapan brainstorming. Fishbone sering digunakan dalam manajemen mutu di industri manufaktur tapi tidak menutup kemungkinan bisa digunakan pada manajemen pemasaran, tujuannya untuk mengidentifikasi dan mengelompokkan penyebab yang menghasilkan masalah kualitas. Secara bertahap, metode ini digunakan juga untuk mengelompokkan ke dalam kategori penyebab jenis masalah lain yang dihadapi organisasi. Hal ini membuat diagram tulang ikan menjadi instrumen yang sangat berguna dalam tahap identifikasi risiko (Masoud Hekmatpanah, 2011). Diagram fishbone biasanya juga digunakan untuk menganalisis suatu kejadian atau proses dengan tujuan untuk mendapatkan atau menemukan hal-hal kemungkinan yang menjadi penyebab pada suatu. Kelebihan yang ada pada diagram fishbone yakni dapat menemukan kemungkinan penyebab permasalahan yang terjadi dan memfokuskan pada sesuatu yang sesuai dengan keadaan, juga dapat diaktualisasikan pada setiap problem yang terjadi.

Implementasi diagram fishbone diawali dari terjadinya sebuah akibat yang timbul dari permasalahan dengan dibuat menjadi daftar terstruktur dari beberfapa penyebab pontensial. Berikut merupakan kelebihan diagram fishbone; Mengkelompokan penyebab yang memungkinkan untuk diindefikasi yang memiliki 
banyak kemungkinan dibanding memfokuskan pada ranah tertentu, kemudian dilanjutkan pada tahapan analisa dan melakukan proses identifikasi terhadap beberapa hal yang menjadi penyebab, terutama yang diduga menjadi penyebab utama. Mengumpulkan gagasan serta masukan yang merupakan inti penting atau dapat dikategorikan dasar dalam proses penggalian gagasan (brainstroming) yang dilakukan secara terstruktur.

Terdapat tiga jenis metode pengembangan diagram sebab akibat yaitu;

1. Jenis analisa disperse digunakan untuk mengorganisasikan dan menghubungkan faktor faktor penyebab dipersi kualitas produk

2. Jenis klasifikasi proses produksi pada jenis ini garis tengah diagram sesuai dengan proses produksi yang mempengaruhi kualitas produsi

3. Jenis enumerasi sebab, pendekatan ini merinci sebab sebab masalah yang mungkin secara sederhana. Diagram enumerasi sebab yang lengkap dapat menyerupai diagram sebab akibat jenis analisa dispersi, perbedaannya bahwa pendekatan ini dimulai dengan merinci sebab-sebab potensial sebanyak mungkin, dengan pendekatan enumerasi mungkin dapat merinci secara lengkap sebab utama masalah, tetapi diagram yang dihasilkan menjadi rumit dan sukar dijelaskan keterkaitan suatu sebab dengan akibatnya.

Prosedur dasar proses pembuatan diagram sebab akibat sebagai berikut (Wignjosoebroto 2006);

1. Memulai dengan pertanyaan mendasar terhadap masalah yang terjadi agar supaya lekas diselesaikan atau teratasi

2. Tuliskan pertanyaan mendasar yang terjadi pada masalah tersebut pada posisi kepala ikan yang merupakan bagian daripada akibat. Kemudian, tuliskan pada bagian kanan kepala ikan, lalu gambarkan tulang belakan dari kiri ke kanan dan tempatkan pertanyaan masalah itu dalam kotak

3. Tuliskan hal-hal yang menjadi penyebab atau kategori utama yang dapat dikembangkan melalui stratifikasi ke dalam pengelompokan dari faktor manusia, mesin, peralatan, material, metode kerja, lingkungan kerja. Pengukuran dan lainnya atau stratifikasi melalui langkah aktual dalam proses faktor penyebab atau katagori yang dapat dikembangkan melalui brainstorming

4. Tuliskan penyebab skunder yang mempengaruhi penyebab skunder (tulang besar) serta penyebab skunder dinyatakan sebagai tulang yang berukuran sedang

5. Tuliskan penyebab persier yang mempengaruhi yang mempengaruhi penyebab skunder pada tulang yang berukuran sedang, serta penyebab persier itu dinyatan sebagai tulang yang berukuran kecil

6. Tentukan item yang paling penting dari setiap faktor dan tandailah faktor penting tertentu yang kelihatannya memiliki pengaruh nyata terhadap karakteristik kualitas 
7. Catatlah informasi yang perlu di dalam diagram sebab akibat itu seperti judul nama produk, proses, kelompok, daftar partisipan, tanggal, dll.

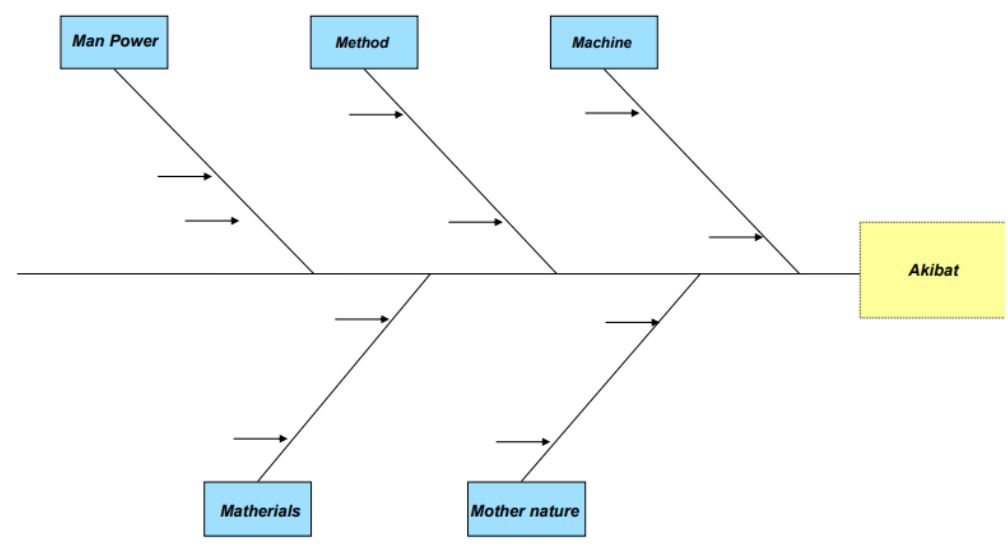

Gambar 2.1 Gambar Diagram Fishbone

\section{METODE PENELITIAN}

Penelitian ini menggunakan metode kualitatif untuk mengungkapkan suatu keadaan atau kondisi sebagaimana adanya berdasarkan hasil pengamatan yang dilakukan dengan pendekatan studi kasus. Data yang diperoleh berbentuk kata-kata atau gambar, sehingga tidak menekankan pada angka. Data diperoleh dari hasil wawancara observasi lapangan dan dokumentasi. Ada lima tahapan dalam penelitian ini yaitu; tahapan identifikasi merupakan tahapan awal dalam menentukan rumusan dan tujuan penelitian yang dilanjutkan pada tahapan pengumpulan dan pengolahan data, tahapan analisis data, dan tahapan pembahasan dan penarikan kesimpulan dan saran.

\section{HASIL DAN PEMBAHASAN}

PT. X merupakan developer perumahan mulai tahun 2009 dengan menggunakan media promosi pemasangan banner di pinggir jalan dan pembagian brosur yang ditaruh di tempat yang biasa dikunjungi orang dan media promosi online dengan memanfaatkan media sosial sebagai sarana promosi produk mereka. Tahun 2019 banyak konsumen yang mengetahui informasi produk PT. X melalui media sosial. Tahun 2020 Indonesia yang juga terdampak Covid-19 membuat adanya pembatasan interaksi sosial sehingga manajemen pemasaran mulai meningkatkan pemasaran melalui media online melalui media sosial. Adanya 
pandemi Covid-19 merupakan salah satu penyebab penurunannya pemasaran di PT. $\mathrm{X}$, namun penurunan pemasaran yang diseabkan oleh pandemi Covid-19 tidak dirasakan oleh PT. X saja tapi juga dirasakan oleh developer perumahan yang lain juga karena perbankan menutup kran pendanaan KPR pada developer perumahan.

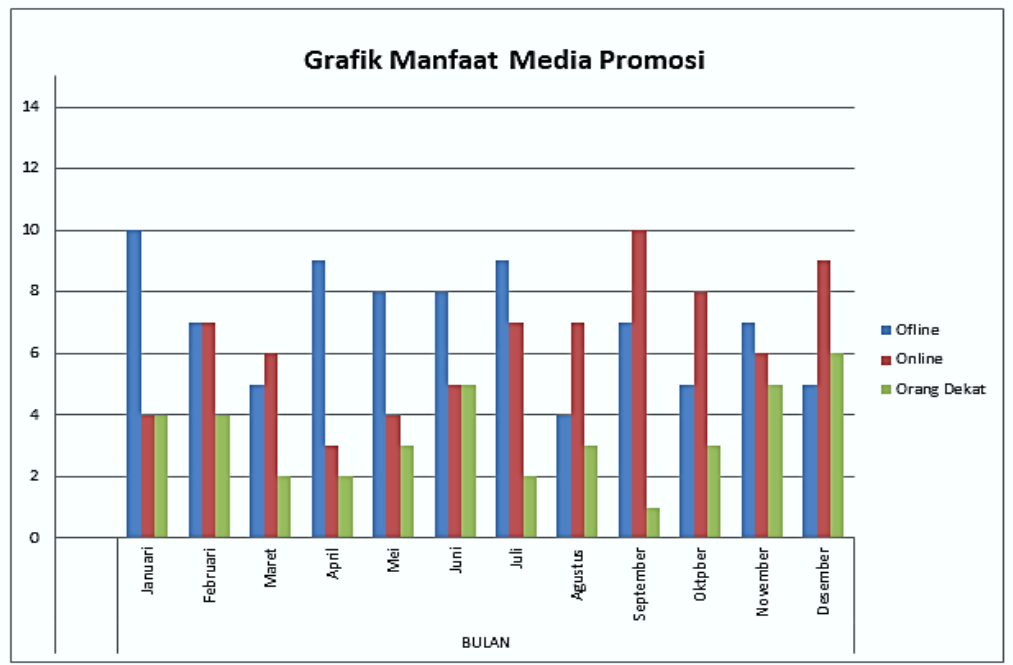

Gambar 4.1 Grafik Pemanfatan Media Promosi PT. X

Gambar di atas menunjukan bahwa ada $42 \%$ konsumen PT. X mengetahui adanya info penjualan melalui dari media online, $38 \%$ mengetahui info pemasaran dari media ofline, dan $20 \%$ dari orang yang mereka kenal dekat. Berdasarkan dari data di atas media online yang menggunakan media sosial lebih efektif daripada penggunaan media ofline yang menggunakan banner dan penyebaran brosur. Pihak manajemen pemasaran sebenarnya sudah melakukan penigkatan promosi menggunakan metode online dengan memanfaatkan media sosial seperti Whatsapp, Facebook, dan Instagram, namun pengelolahan media sosial PT. X menggunakan smartphone pribadi yang dipegang karyawan selain itu menurut tim media pengambilan gambar PT. X pengambilan gambar yang digunakan dalam promosi masih menggunakan $\mathrm{Hp}$ pribadi sehingga hasil pengambilan gambar kurang maksimal. Kurangnya dukungan sarana yang diberikan oleh PT. X menyebabkan kurangnya kreatifitas karyawan dalam menggunakan media dan metode pemasaran menjadi sebab penurunannya pemasaran PT. X.

Iklan pemasaran yang menggunakan metode online melalui media sosial desain promosi yang menggunakan metode online menurut masyarakat yang ditemui peneliti PT. X masih kalah dari pesaingnya. Masyarakat menganggap desain foto dan video yang digunakan PT. X kurang bagus untuk dijadikan sebagai promosi sehingga mereka hanya skip video promosi yang disebarkan PT. X. Adanya permasalahan di sektor machine tidak adanya dukungan sarana promosi yang disediakan oleh manajemen pemasaran PT. X merembet ke man power tidak kreatif dan termotivasi dalam melakukan pemasaran yang disebabkan keterbatasan sarana, hasil wawancara dari berbagai sumber juga menunjukan bahwa karyawan 
masih membutuhkan pelatihan dalam pemanfaatan media dan metode pemasaran karena sementara ini karyawan memang jarang dan hampir tidak pernah ada pelatihan dalam pemanfaatan media dan metode pemasaran. Data di atas menunjukan faktor machine, man power dan mehod menjadi salah satu penyebab menurunnya pemasaran PT. X.

PT. X juga masih belum memiliki SOP tertulis atau baku dalam pemasaran, baik dari segi promosi ataupun pembelian perumahan yang dilakukan oleh user. Para karyawan hanya melakukan promosi sebagaimana yang telah diintruksikan oleh manajer jadi ketika ada user yang melakukan pembelian ditangani masingmasing marketing untuk proses pembelian dan dilanjutkan ke CSO untuk menyerahkan berkas ke pihak perbankan untuk diproses, jika berkas lolos maka dilanjutkan ke pembangunan dan serah terima perumahan.

\section{SERVICE LEVEL AGREEMENT}

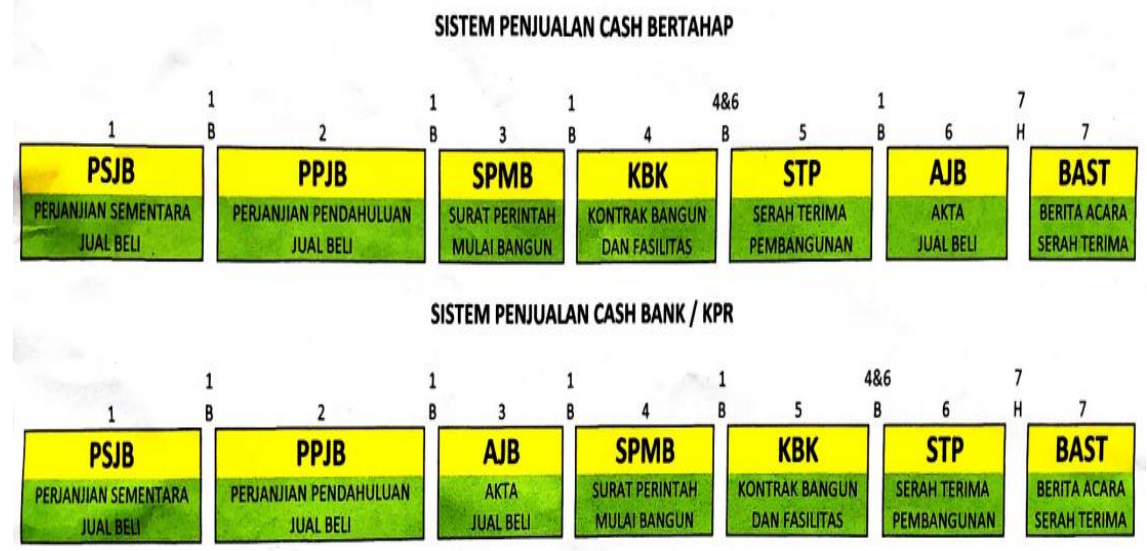

Gambar 4.2 Sistem Penjualan PT. X

Gambar di atas menunjukan tentang sistem penjualan secara cash bertahap dan sistem penjualan cash bank atau KPR perumahan PT X masih belum menunjukan sebuah SOP penjualan, hal ini bisa menjadi sebuah akibat penjualan yang tidak terkontrol secara sistematis dan sesuatu yang tidak munkin terjadi wase dalam pengelolahan administrasi PT. X kedepannya jika tidak adanya SOP yang diterapkan dalam penjualan. 


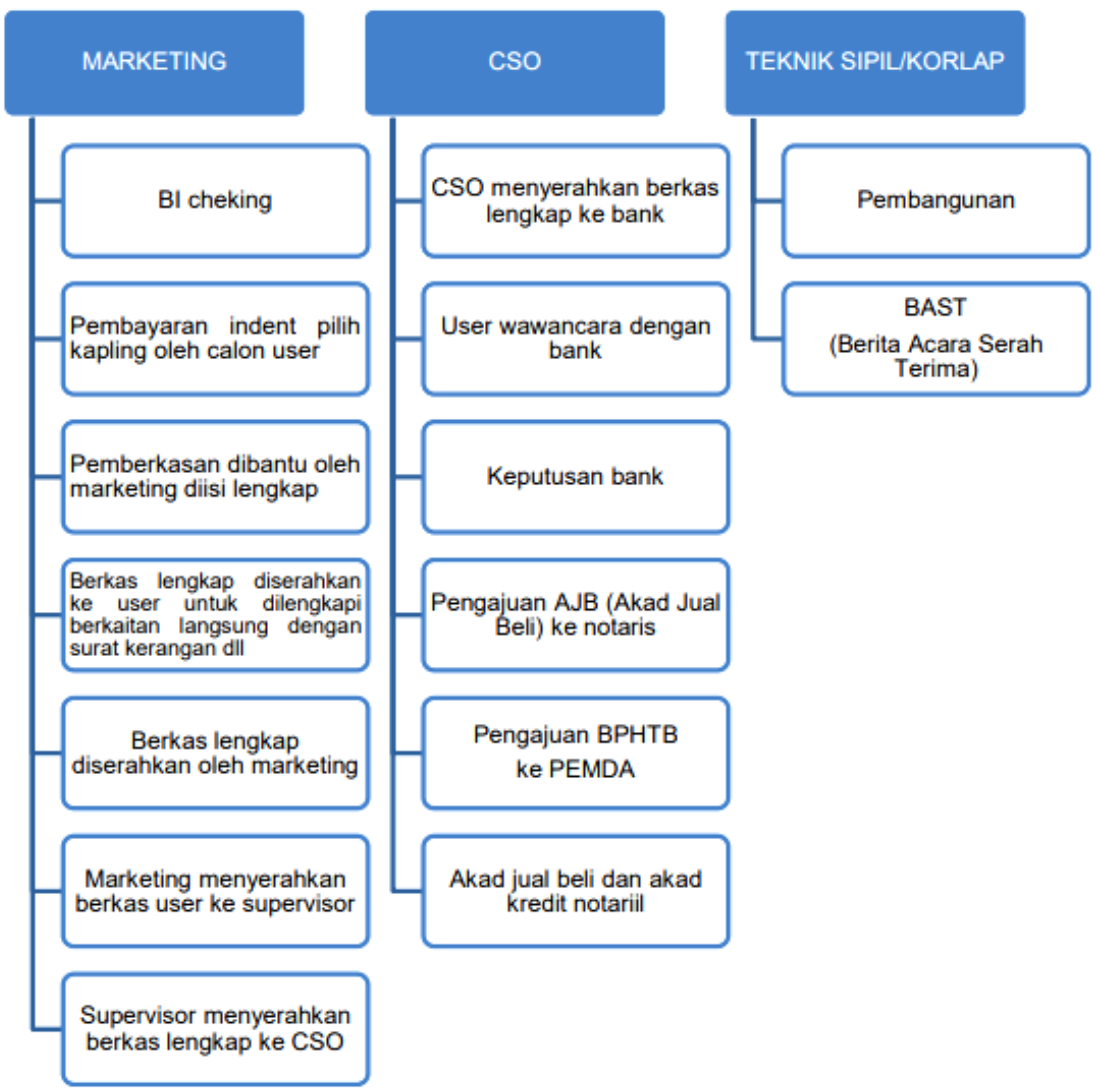

Gambar 4.3 Alur Kerja Closing Perumahan (Proses KPR) PT. X

Gambar alur kerja closing perumahan PT X di atas juga masih belum menunjukan sebuah SOP penjualan melainkan hanya alur kerja kerja closing perumahan (proses KPR). Hal tersebut menunjukan bahwa sebenarnya PT. X masih belum memiliki SOP dalam melaksanakan sistem penjualan. Menurut costumer, administrasi pembelian perumahan dibantu oleh marketing sehingga bisa cepat namun untuk melengkapi persyaratan administrasi yang diberikan PT. X masih terkesan merepotkan dan membuat costumer bingung dan bolak-balik dalam melengkapi melengkapi persyaratannya. Dari beberapa keterangan di atas menunjukan bawa penyebab menurunnya peasaran juga dikarenakan tidak adanya SOP pemasaran yang dimiliki PT. X.

Metode pemasaran yang digunakan dalam memasarkan produk PT. X yang melalui ofline dengan menggunakan banner ditaruh di pohon dipinggir jalan juga terkesan monoton dan pemborosan dalam pelaksanaan promosi, pihak manajemen pemasaran mengurangi penggunaan banner yang ditaruh di pohon, tim pemasaran menggantinya dengan menggunakan banner yang dipasang di billboard dengan harga sewa yang cukup mahal sehingga pemasangan banner di billboard hanya 
dilakukan di daerah kota Lumajang saja. Metode pemasaran yang menggunakan penyebaran brosur biasanya disebarkan diperkampungan, dititipkan di rumah makan atau di tempat tertentu, penyebaran brosur biasanya juga dilakukan di instansi yang salah satu anggotanya sudah menjadi costumer perumahan pada PT. X, metode penyebaran brosur yang dilakukan di sebuah instansi biasanya disertai dengan sosialisasi pengenalan produk PT. X tapi metode ini masih jarang dilakukan oleh tim promosi PT. X. Brosur yang disebarkan memuat varian tipe perumahan beserta harga jualnya, persyaratan yang harus dipenuhi oleh pembeli dan contact person yang dapat dihubungi.

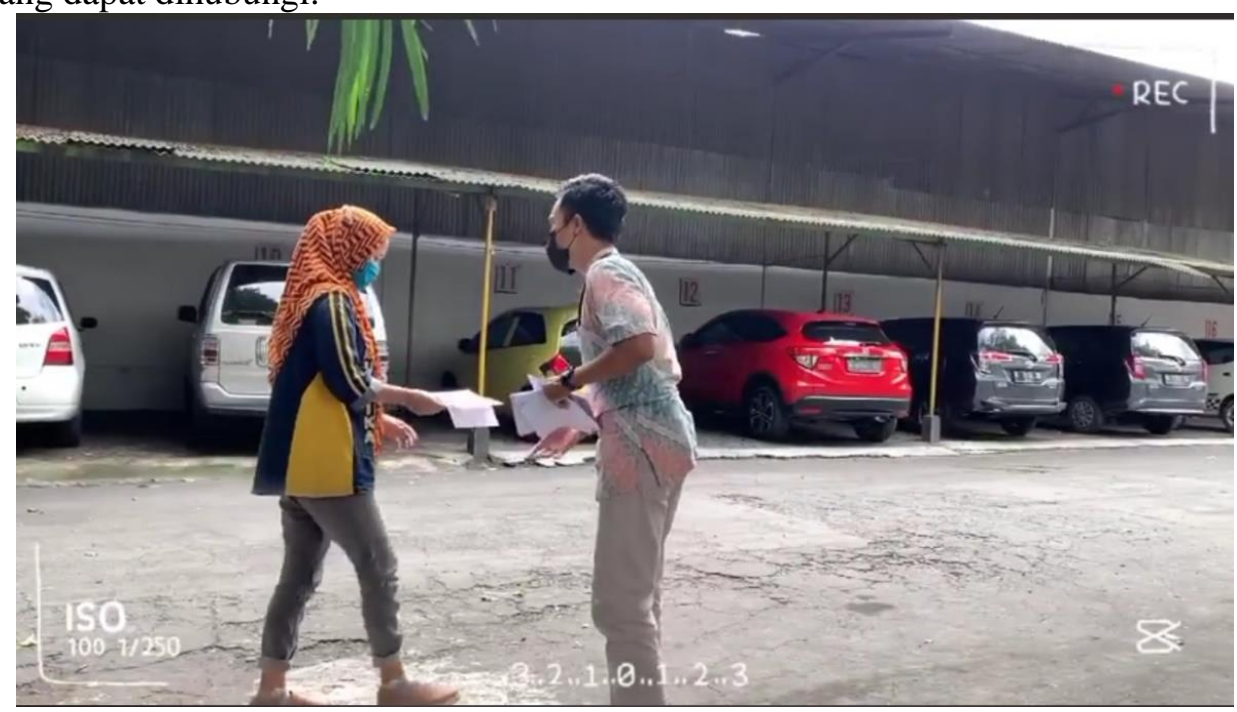

Gambar 4.4 Dokumen Screnshoot Video Sosialisasi produk PT. X (Sumber Facebook PT. X)

Gambar di atas menunjukan tim promosi PT. X membagikan brosur pada masyarakat yang di dalamnya sudah tertera varian harga produk PT. X dan contact person yang bisa dihubungi costumer. Menurut tim pemasaran tidak ada aturan baku dalam menyebarkan brosur pada masyarakat Lumajang kecuali penyebaran brosur yang dilakukan disebuah instansi harus diketahui dan disetujui oleh manajer pemasaran PT. X.

Pemasaran produk PT. X juga melibatkan orang di luar tim pemasaran yang membawa costumer perumahan untuk membeli perumahan di PT. X akan diberikan bonus sebesar 1\% setelah terjadi kesepakatan antara pembeli dengan pihak developer. Produk PT. X yang terjual melalui perantara orang di luar tim banyak daripada langsung lewat tim pemasaran, namun menurut salah satu karyawan PT. X menyatakan bahwa sebenarnya metode penjualan dengan melalui perantara awalnya dari adanya tim pemasaran PT. X tidak bisa memenuhi target pemasaran individu yang telah ditentukan, setiap individu ditargetkan paling sedikit bisa menjual dua unit perumahan dalam satu bulannya, namun dari hasil wawancara dan observasi 
menunjukan bahwa tidak semua karyawan memenuhi target individu penjualan, meski demikian target bulanan PT. X terpenuhi.

Pelayanan cek lokasi yang diberikan oleh PT. X ataupun juga sama memuaskan sama seperti yang diberikan oleh pesaing mereka. Para konsumen yang datang langsung ke lokasi perumahan yang dijual juga mendapatkan pelayanan yang memuaskan sebab mereka bisa mengetahui produk secara langsung dan dijelaskan tentang spesifikasi produk yang ditawarkan oleh karyawan yang bertugas dilokasi perumahan. Dari data yang didapatkan juga sesuai dengan hasil observasi yang peneliti lakukan di lapangan.

Lokasi pemasaran PT. X juga cukup strategis karena berdasarkan para konsumen PT. X dan masyarakat sekitar menjelaskan bahwa lokasi perumahan PT. $\mathrm{X}$ dinilai strategis karena jarak dari pusat kota tidaklah jauh, hanya berjarak $\pm 5 \mathrm{~km}$ dan paling jauh $\pm 10 \mathrm{~km}$ dari pusat kota dibandingkan dengan dengan pesaing mereka. Lingkungan perumahan PT. X juga asri dan tidak bising meskipun dekat dengan pusat kota, kultur yang ada di lokasi perumahan PT. X juga nyaman se meskipun terletak di dekat pusat kota. Keamanan perumahan PT. X juga terjamin karena pos penjagaan 24 jam dan dilengkapi oleh CCTV yang diletakan di beberapa sudut perumahan untuk memantau keamanan.

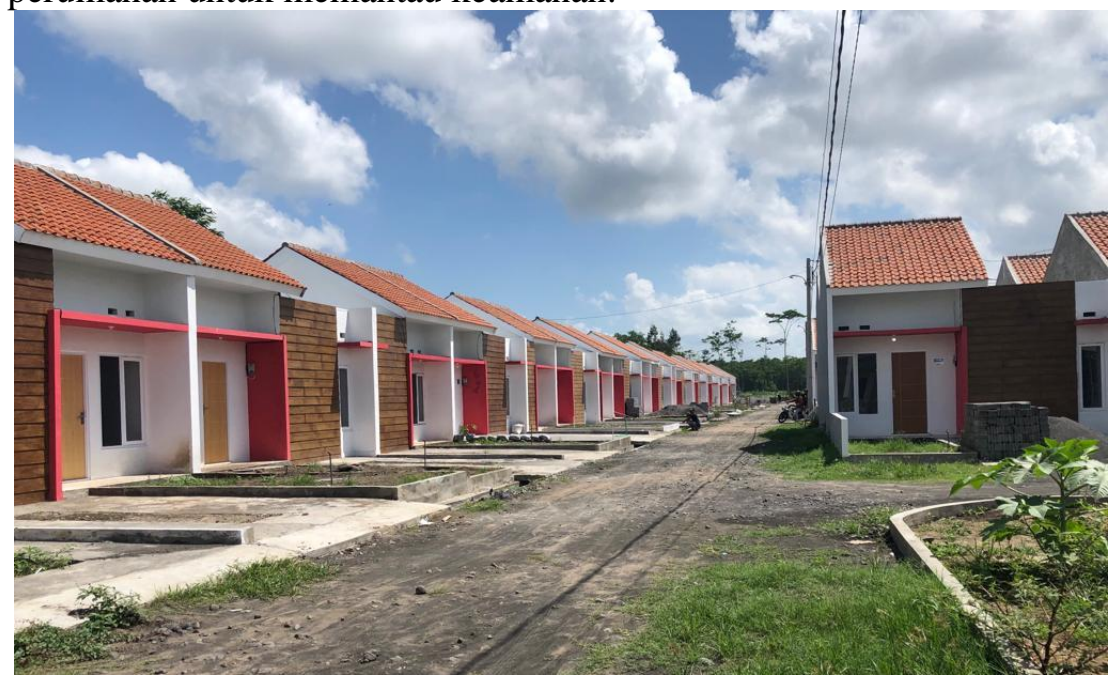

Gambar 4.6 Lokasi Perumahan PT. X

Gambar di atas menunjukan lokasi perumahan PT. X yang terasa asri dan jauh dari kebisingan meskipun jarak perumahan bisa dibilang dekat dengan pusat kota Lumajang. Pemilihan lokasi perumahan PT. X ditentukan oleh pihak pimpinan langsung bukan dari karyawan sedangkan untuk material pembangunan juga tidak pernah kehabisan stok karena menurut pekerja pembangunan, material pembangunan jika hampir habis mereka minta langsung diantarkan, namun setelah ditanyakan apakah ada catatan rekapitulasi material yang digunakan dalam pembangunan mereka menjawab tidak karena untuk material sudah diatur dan langsung oleh manajer PT. X. Menurut manajer PT. X pencatatan material yang 
digunakan hanya direkap manual. Menurut masyarakat yang ditemui peneliti, ada perbedaan dengan para pesaing PT. X yaitu penggunaan bahan bata, bata yang digunakan PT. X yaitu bata putih sedangkan para pesaingnya menggunakan bata merah sehingga menurut masyarakat produk PT. X lebih terkesan lebih mahal. Hal itu sesuai dengan yang disampaikan oleh tim pembangunan PT. X. PT. X memilih menggunakan bata putih daripada menggunakan bata merah dikarenakan masyarakat lebih mempercayai penggunaan bata merah lebih kuat daripada penggunaan bata merah. Hal itu juga sesuai dengan hasil obsevasi lapangan.

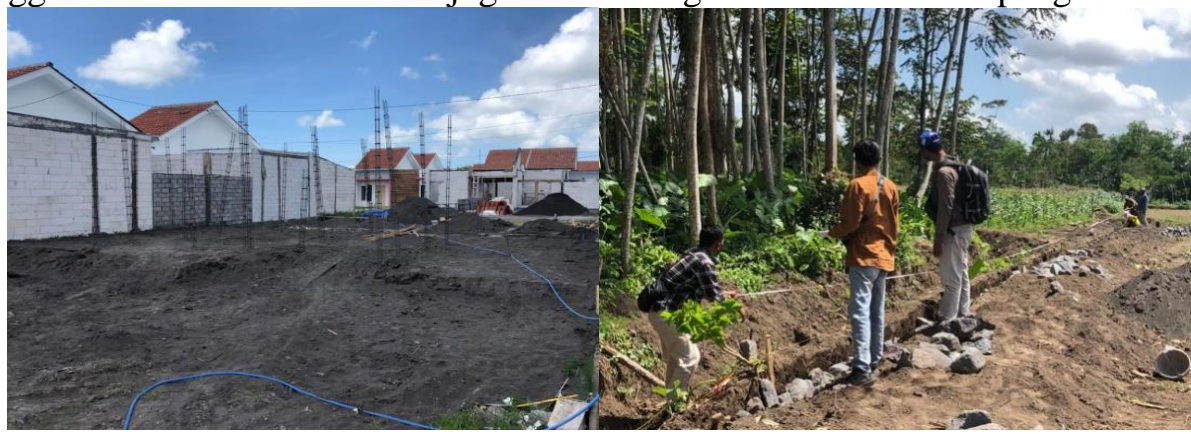

Gambar 4.7 Material Pembangunan Perumahan PT. X

Gambar di atas merupakan gambar proses pembangunan pagar belakang perumahan PT. X dan material tembok yang menggunakan bata putih, menurut masyarakat yang ditemui peneliti mereka menyarankan kedepannya PT. X seharusnya menggunakan penggunaan bata merah untuk meningkatkan penjualannya dalam penggunaan material karena sebenarnya masyarakat Lumajang beranggapan bahwa penggunaan bata merah lebih kuat daripada penggunaan bata putih dan mereka beranggapan bahwa penggunaan bata putih terkesan lebih murah daripada bata merah, hal itu juga sesuai dengan penyampaian masyarakat Lumajang yang bekerja dalam bidang pembangunan bahwa penggunaan bata merah lebih kuat daripada penggunaan bata putih.

Menurut masyarakat Lumajang harga yang diberikan oleh PT. X tidak jauh beda dengan developer perumahan yang lainnya, dan untuk metode pembayarannya bisa melalui cash dan kredit melalui KPR sama dengan developer perumahan yang lainnya tapi untuk perumahan yang tipe komersil PT. X menyediakan program pembayaran in house, program in house merupakan program pembayaran dengan jangka waktu yang telah disepakati pihak developer dan pembeli dengan jangka waktu pembayaran paling lama dua tahun.

PT. X juga masih belum memiliki aplikasi data perusahaan keseluruhan pelaporan yang terintegrasi berbasis online ataupun ofline, sistem pencatatan pelaporan yang digunakan oleh PT. X masih menggunakan aplikasi excel sebagai rekapitulasi pelaporan pada manajer perusahaan. Aplikasi saat ini yang digunakan dalam memuat pelaporan penjualan terkesan ribet dan tidak tertata, bahkan ketika ditemui dan ditanya tentang rekapituasi proses pembangunan dan penjualan PT. X menurut mereka entah ada atau tidak laporannya. Menurut karyawan PT. X perusahaan memang masih belum memiliki aplikasi terpadu yang memuat data 
perusahaan baik data produk yang masih progres pembangunan, penjualan dan data yang sudah terjual. Absensi karyawan setiapharinya menggunakan fingger print di kantor sebagai absensi awal dan ketika berganti siff mereka melaporkannya melalui aplikasi Whatsaap group. Hal tersebut senada dengan yang disampaikan oleh manajer PT. X bahwa perusahaan masih belum memiliki aplikasi terpadu yang memuat data perusahaan, stok material pembangunan, progres pembangunan dan data produk yang sudah terjual, dalam pesanan atau masih belum terjual.

Hasil perolehan data dan analisis peneliti menunjukan bahwa penyebab turunnya pemasaran PT. X berasal dari kurangnya pelatihan dan motivasi karyawan di indikator man power, tidak adanya SOP penjualan dan kurangnya kreativitas dalam penggunaan metode pemasaran di indikator method, kurangnya dukungan sarana ada indikator machine, penggunaan bahan dasar bangunan pada indikator matherials, dan adanya pandemi Covid-19 serta banyaknya perusahan baru (pesaing) di mother nature. Kurangnya dukungan sarana dan tidak adanya aplikasi sistem yang terintegrasi berdampak pada pengelolahan administrasi penjualan yang tidak terkontrol secara sistematis Berikut hasil iddentifikasi PT. X jika ditaruh pada diagram fishbone:

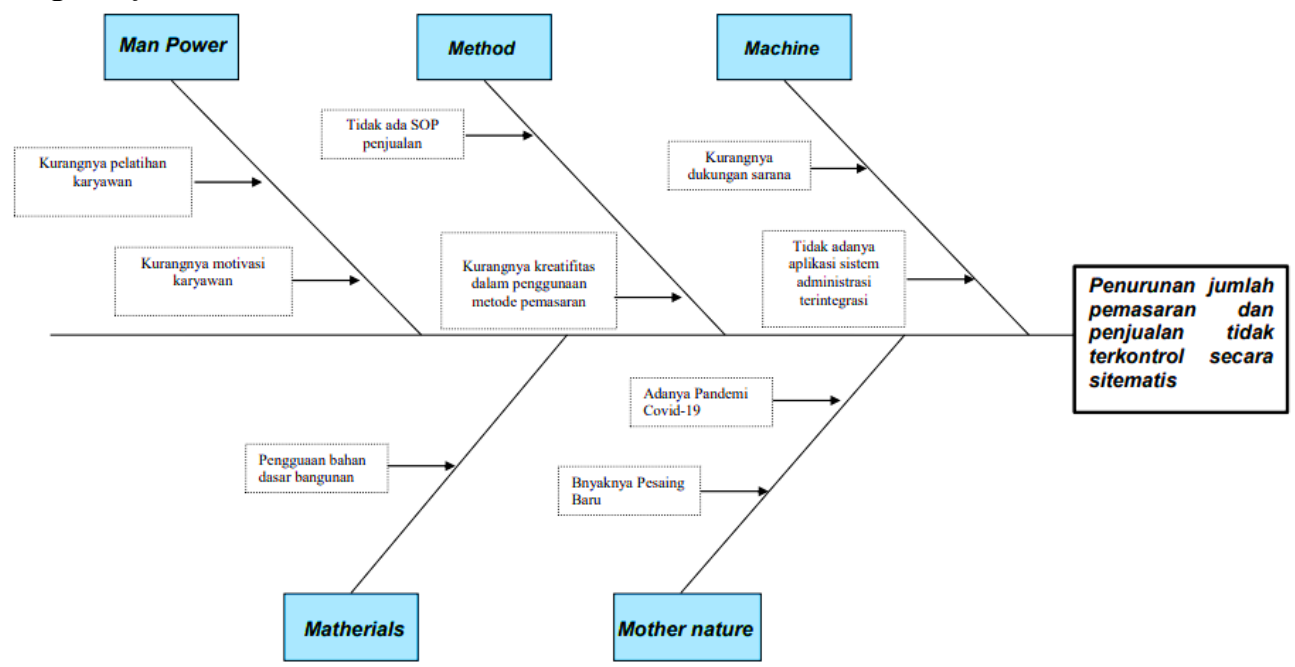

Gambar 4.9 Hasil Diagram Fisbone PT. X

Gambar fishbone di atas menunjukan bahwa sebenarnya PT. X memiliki penyebab yang berasal dari man power, method, manhine, materials dan mother natur sehingga menyebabkan penurunan pemasaran dan pengelolahan administrasi yang tidak tertata dan terkontrol secara sistematis.

\section{KESIMPULAN}

Hasil pembahasan di atas menunjukan bahwa PT. X menggunakan strategi pemasaran online dengan memanfaatkan media sosial dan untuk strategi pemasaran ofline menggunakan penyebaran brosur yang disebarkan pada masyarakat serta 
melalui sosialisasi pengenalan produk yang dilakukan di instansi. Hasil diagram fishbone penyebab penurunan jumlah pemasaran dan penjualan tidak terkontrol secara sistematis di PT. X berasal dari faktor man power kurangnya pelatihan dan motivasi karyawan, method tidak adanya SOP penjulan, kurangnya kreatifitas karyawan dalam penggunaan metode pemasaran dan manchine kurangnya dukungan sarana pembuatan iklan pemasaran dan pengelolahan administrasi serta tidak adanya sistem pendukung administrasi.

\section{SARAN}

PT. X kedepannya menjadikan acuan dalam melakukan perbaikan sistem pemasaran terutama faktor sumber daya manusia dan sistem layanan untuk mempermudah costumer dalam pembelian untuk mencapai visi dan misi PT. X. Penelitian selanjutnya diharapkan bisa lebih memperdalam penelitian terkait dengan strategi pemasaran PT. X untuk mengembangkan penelitian ini.

\section{DAFTAR PUSTAKA}

Asmara, Jimi. 2021. "RANCANG BANGUN APLIKASI E-MARKETING PADA DEALER MOBIL XYZ KUPANG BERBASIS WEB.” Prosiding Seminar Nasional Aplikasi Sains \& Teknologi (SNAST): 53-65.

Cahyono, Basuki, Andi Tri Haryono, and Djamaludin Malik. 2017. "Analisa Kekuatan Strategi Pemasaran Melalui Online Marketing, Offline Marketing Dan Service Excellent Terhadap Loyalitas Konsumen Pt. Adinata Graha Raya Kaliwungu Dengan Kepuasan Konsumen Sebagai Variabel Intervening." $\begin{array}{llll}\text { Journal of } & \text { 3(3): }\end{array}$ http://jurnal.unpand.ac.id/index.php/MS/article/view/714.

Caturini, Siska Julinda, ZA, Moh. Ah. Subhan, and Ahmad Ubaidillah. 2020. "Analisis Strategi Pemasaran Pada Media Sosial (Study Kasus Strategi Pemasaran Syariah Pada Perumahan Syariah Grand Zam-Zam Residence Di Lamongan)." Sawabiq : Jurnal Keislaman 1(1): 1890-96.

Chryssoula Chatzigeorgiou Evangelos Christou. 2020. "Adoption of Social Media as Distribution Channels in Tourism Marketing: A Qualitative Analysis of Consumers' Experiences." Journal of Tourism, Heritage \& Services Marketing 6(1): 25-32.

Ernst C. Osinga, Menno Zevenbergen, Mark W.G. van Zuijlen. 2019. "Do Mobile Banner Ads Increase Sales? Yes, in the of Fl Ine Channel." International Journal of Research in Marketing 36(3): 439-53. https://doi.org/10.1016/j.ijresmar.2019.02.001.

Fernando, Yusra, Imam Ahmad, Arief Azmi, and Rohmat Indra Borman. 2021. "Penerapan Teknologi Augmented Reality Katalog Perumahan Sebagai Media Pemasaran Pada PT . San Esha Arthamas." Jurnal Sains Komputer \& $\begin{array}{lll}\text { Informatika } & \text { (J-SAKTI) }\end{array}$ https://tunasbangsa.ac.id/ejurnal/index.php/jsakti Penerapan.

Iis Mincarti, Herry Mulyono. 2020. “Analisis Dan Perancangan Sistem Informasi 
Persediaan Produk Berbasis Web Pada Pt Ai." MANAJEMEN SISTEM INFORMASI 5(4): 70.

Iriani, Yani et al. 2020. "QUALITY CONTROL ANALYSIS OF STAMPING PRODUCT WITH STRATIFICATION , PARETO DIAGRAM , CONTROL DIAGRAM , AND ISHIKAWA DIAGRAM AT PT . X.” 32(3): 6208-14.

Kemendag. 2014. "Undang-Undang No 7 Tahun 2014 Tentang Perdagangan." : 1-80. http://www.kemendag.go.id/files/regulasi/2014/03/11/7-tahun-2014-id1398758805.pdf.

—. 2019. "Peraturan Pemerintah RI Nomor 80 Tahun 2019 Tentang Perdagangan Memalui Sistem Elektronik." : 1-3. https://www.kemendag.go.id/id/newsroom/press-release/pp-nomor-80-tahun2019-pemerintah-lahirkan-peraturan-pemerintah-tentang-perdaganganmelalui-sistem-elektronik-1.

Khodijah, Syarifah Labibah. 2015. "Analisis Faktor-Faktor Penyebab Kerusakan Produk Pada Proses Cetak Produk." UNIVERSITAS DIPONEGORO.

Marchand, André, Thorsten Hennig-Thurau, and Jan Flemming. 2020. "Social Media Resources and Capabilities as Strategic Determinants of Social Media Performance." International Journal of Research in Marketing (xxxx).

Mulyana, Ahmad et al. 2020. "ICT and Social Media as a Marketing Communication Platform in Facilitating Social Engagement in the Digital Era." International Journal of Innovation, Creativity and Change 13(5): 1-16. www.ijicc.net. 